This item was submitted to Loughborough's Research Repository by the author.

Items in Figshare are protected by copyright, with all rights reserved, unless otherwise indicated.

\title{
A boundary-based view of product development—a feasibility study
}

PLEASE CITE THE PUBLISHED VERSION

PUBLISHER

(C) IMechE / Professional Engineering Publishing

VERSION

VoR (Version of Record)

LICENCE

CC BY-NC-ND 4.0

REPOSITORY RECORD

Smart, P.K., N.J. Brookes, F.E. Lettice, C.J. Backhouse, and Neil D. Burns. 2019. "A Boundary-based View of Product Development—a Feasibility Study”. figshare. https://hdl.handle.net/2134/4565. 
This item was submitted to Loughborough's Institutional Repository (https://dspace.lboro.ac.uk/) by the author and is made available under the following Creative Commons Licence conditions.

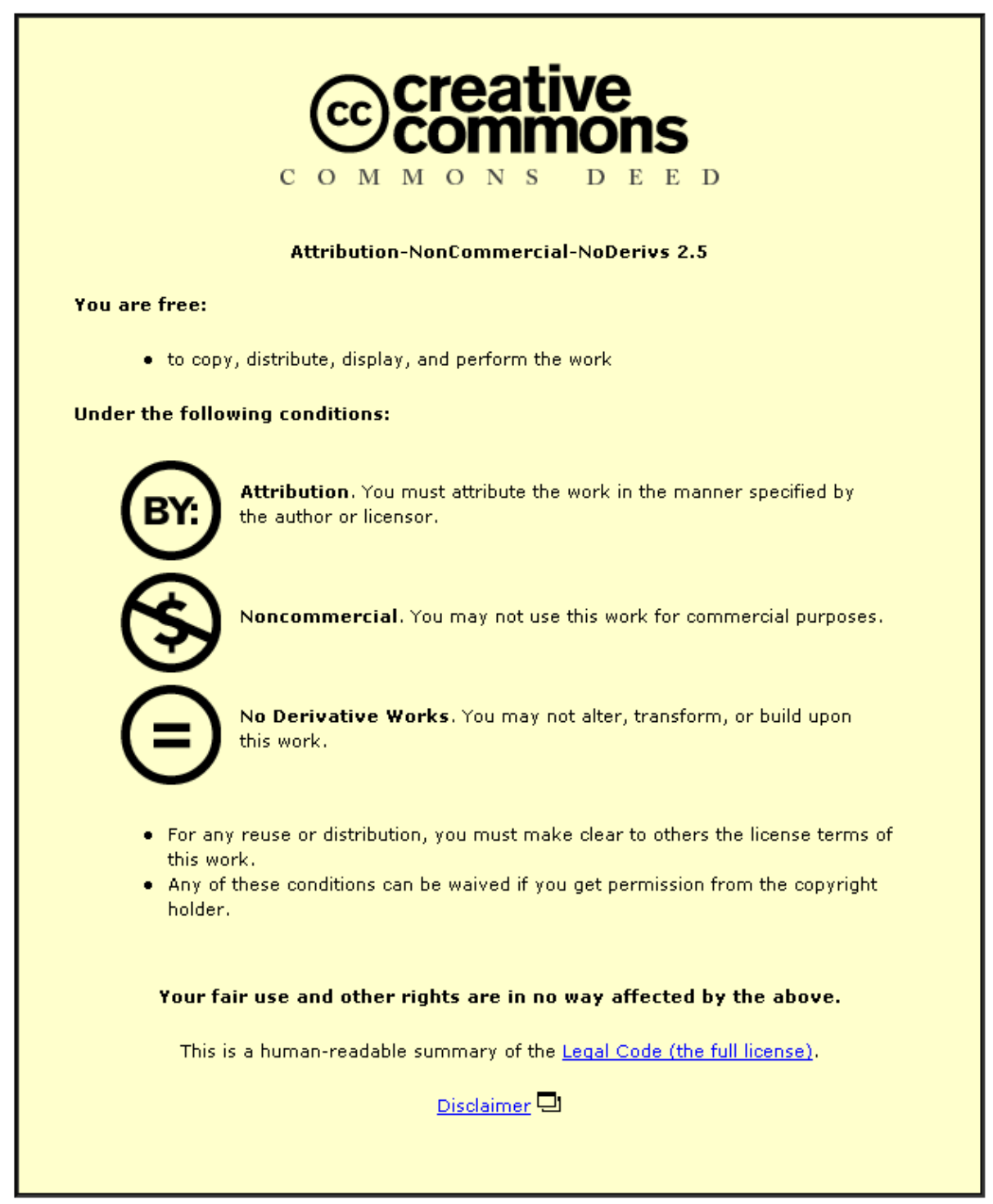

For the full text of this licence, please go to: http://creativecommons.org/licenses/by-nc-nd/2.5/ 


\title{
A boundary-based view of product development- a feasibility study
}

\author{
P K Smart ${ }^{1 *}$, N J Brookes ${ }^{2}$, F E Lettice ${ }^{3}$, C J Backhouse ${ }^{2}$ and N D Burns ${ }^{2}$ \\ ${ }^{1}$ Advanced Management Research Centre, Cranfield School of Management, Cranfield, Bedfordshire, UK \\ ${ }^{2}$ The Department of Manufacturing Engineering, Loughborough University, Loughborough, Leicestershire, UK \\ ${ }^{3}$ International Ecotechnology Research Centre, Cranfield University, Cranfield, Bedfordshire, UK
}

\begin{abstract}
The 'Working the Boundaries' research project investigates the organization structural changes in the Rover Group arm of the BMW AG corporation. An important aim of this research is to determine the feasibility of a 'boundary-based' view to organizing human resources during product development. This viewpoint stresses the need for firms to consider not only the strategic placement of formal organizational boundaries but also the concurrent development of innovative options for overcoming them. This paper presents some important grounded theoretical developments. They focus on the identification of an important mechanism-the informal organization used to overcome formal organization boundaries. The informal organization is based on a network of self-generated, self-organized and self-managed interrelationships between product developers. They form the foundations of effective and efficient flows of information, experience, knowledge and ideas during product development task activity. Consequently product development performance relies significantly on a formal recognition of the informal organization.
\end{abstract}

Keywords: boundaries, product development, formal organization, informal organization, networks

\section{INTRODUCTION}

The focus of late twentieth century competitive product development strategies has primarily been the integration of different functional skills, knowledge and expertise [1-4]. This is generally accepted as a progression from the traditional functionally structured organization and has resulted in the overwhelming advocation of multifunctional project teams to organize for product development activity. However, team- and projectbased product development has not come without its ills [5-8].

If there are advantages and disadvantages associated with both project and the traditional functional organizations, then it may be supposed that there is some optimal point for product development lying along the spectrum between them. However, research by Henderson [9] from the Sloan Management Institute at the Massachusetts Institute of Technology indicates that searching for this 'optimal' point is a fruitless exercise. This work, based in the pharmaceutical industry, indicates that it is not the

The MS was received on 9 November 2000 and was accepted after revision for publication on 24 July 2001.

*Corresponding author: Advanced Management Research Centre, Cranfield School of Management, Cranfield, Bedfordshire MK43 OAL, $U K$.

B11700 (C) IMechE 2002 type of organization structure adopted by companies that governs their product development success. It is the ability of the company to overcome the boundaries of any organizational grouping in a fashion, which dictates the company's achievements. Henderson states that:

Success (in product development) is not a function of a particular organisational choice. Indeed the most successful companies in our study were those that were never satisfied with any single answer.

The 'Working the Boundaries' project sought to corroborate these propositions in a different industrial environment to that of Henderson's original study by carrying out a longitudinal case study with an automotive company-Rover Group. The project's hypothesis was as follows:

H1: Manufacturing organisations that acquire and exercise capabilities to overcome boundaries in their organisational structure can improve product development performance.

This paper presents some of the grounded theoretical developments, which are giving some support to Henderson's viewpoint of organizational boundaries. Further findings are also echoing those of Krackhardt and Hanson [10], Farris [11], Baker [12], Nohria and Eccles [13], Liedtka et al. [14], Athaide and Stump [15] and Bouty [16]. 


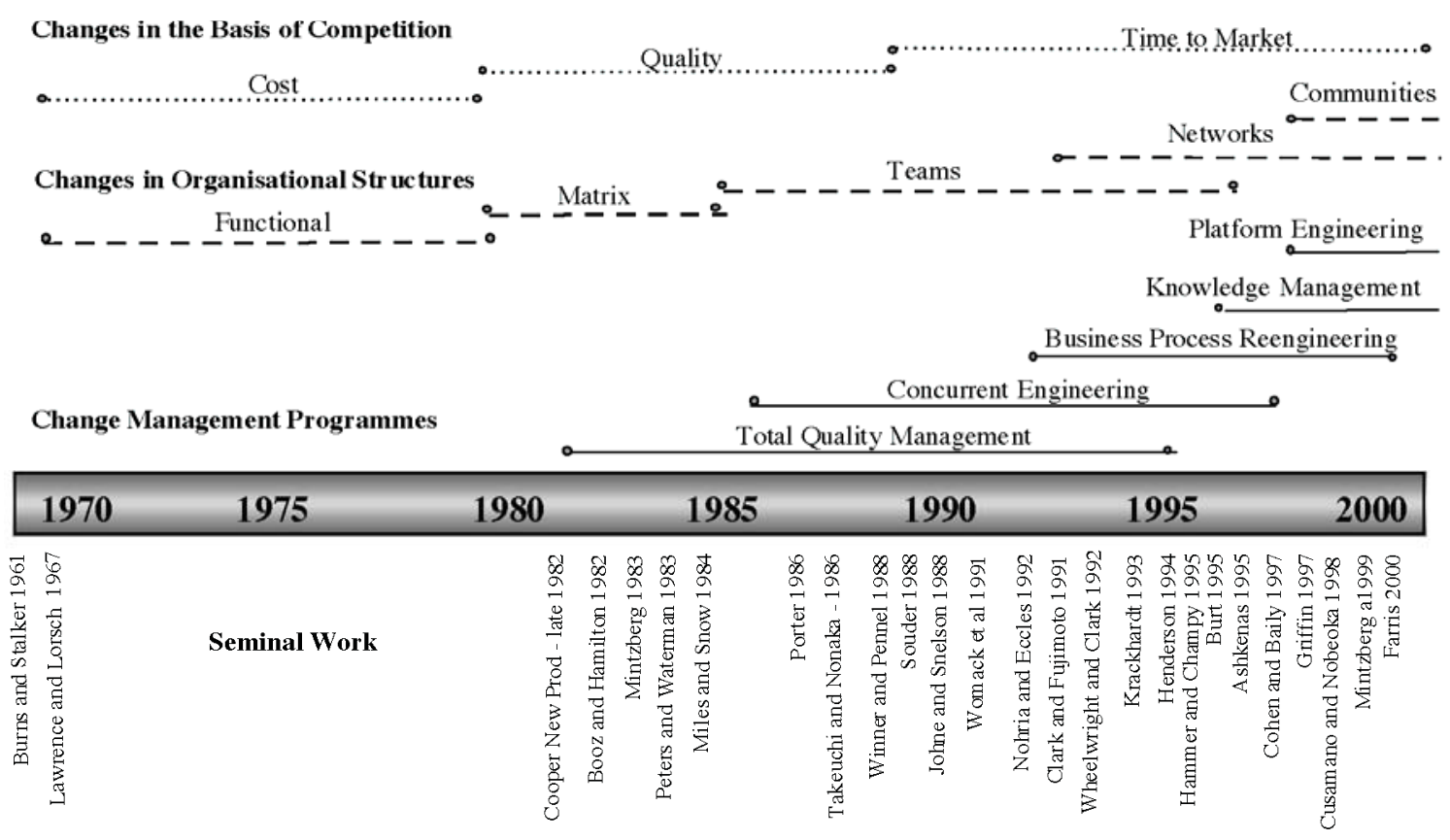

Fig. 1 Timeline of organization theory and practice

While discussing the research findings in the context of existing theory this paper considers the notion of both formal and informal organizational boundaries. The informal organization based on a network of productive relationships is described. Its importance as a mechanism for overcoming formal organizational boundaries through a process of 'informal repositioning' will be shown. Future lines of academic enquiry to generate a more unifying theory of organization structure will also be proposed.

\section{LITERATURE REVIEW}

Improving product development performance, through changes in organizational structure, has been and still is an important goal for many researchers. Studying the impact of organizational structure on product development project performance has its roots in the age of mass production. The period of Fordism and Taylorism had dominated over the first half of the twentieth century. Increasing levels of global competition, fragmentation of markets and uses of new technology were showing the traditional functional organizations to be an enviable option. It was seen to be unable to cope with rapidly changing customer aspirations of the 1980s and 1990s and those expected in the twenty-first century.

A review of the relevant literature has shown an interesting progression in organizational theory and practice over the last 30 years. Many companies starting out as functional organizations have moved through the phases of being matrix, team based, networked and now resemble communities as shown in Fig. 1.

Classical theories suggest that the impact of contingent factors such as the market environment on organizational structure should not be ignored. Contingency theorists therefore argue that organizations will be more effective if they are designed to 'fit' the nature of their primary task. Therefore organizations should adopt a mechanistic form if their tasks are simple and stable to ensure the goals of efficiency [17]. However, they should adopt an organic structure if their tasks are complex and frequently changing.

The later part of the twentieth century movement to improve product development performance adopted integration strategy to sit at the heart of 'change management' programmes such as total quality management, concurrent engineering [2], re-engineering [18] and, more recently, knowledge management [19], platform management [20, 21] and brand management [22]. However 'integration' alone can no longer provide organizations with the competitive edge required to survive the dynamic global business environment of today and the near future.

A new wave of thinking began to dominate the organization theory literature in the early 1990s. Its conceptual origins date back to the 1960s' social theory and 1980s' organizational theory [23]. It is more sympathetic to the role of the individual with the organization and is called network theory [13]. The term 'network organization' is becoming increasingly popular in both theory and application. It has been used with reference to different industries by Burns and Stalker [17], Mintzberg [24], 
Miles and Snow [25], Eccles and Crane [26] and Gulati et al. [27]. Baker [12] suggests that the network form can be designed to handle product development tasks and market environments that demand flexibility and adaptability. However, the limitations of network organization theory surround the dynamic nature of the 'lifecycle' of a network relationship.

An important arm of network theory investigates the concept of an informal organization. In particular it demonstrates the relevance of people's networks of relationships as shown by the work of Krackhardt and Hanson [10], Burt [28], Krackhardt and Kilduff [29], Newell et al. [30] and Farris [31].

Today's post-Fordist era is increasingly being characterized by organizations that do not want to create a non-human monolith, producing narrow product portfolios, with little choice for customers and poor customer service. Increasingly work is organized in a more organic way susceptible to rapid continuous and discontinuous change. There are also many examples of organizations which have benefited from this method of operation and now stand as role models (e.g. GE, AT\&T, Chrysler, Toyota and Microsoft, Lastminute.com, Amazon.com) for the international business community.

\section{RESEARCH METHODOLOGY}

In testing Henderson's [9] work more widely, it may have been considered appropriate to carry out survey research with as wide a sample of companies as possible. This approach was rejected for the following reasons:

1. Survey research will only give information on the questions that are asked in the survey. This project is at a feasibility stage especially with regard to identifying potential mechanisms to overcome formal organization boundaries. Mintzberg [32] suggests that at this stage those descriptive methodologies such as case studies should be pursued rather than the creation of 'less valid data that were statistically significant'.

2. The investigators found in previous research that the performance measurement data that they require for this type of investigation are not readily available from companies and require a significant amount of work on the part of both the researchers and the company to be extracted [33]. It would therefore be very difficult to elicit this in a survey situation.

The generality of a survey approach was therefore rejected in favour of the richness of information that could be achieved from a longitudinal case study with one particular organization - the Rover Group arm of the BMW AG Corporation. The investigation was both exploratory and descriptive, aiming to provide holistic and meaningful interpretations of real-life events in their natural settings. Together this helped to generate novel grounded theoretical developments concerning organizational structure and its impact on product development performance. A non-probability sampling technique was considered more appropriate for an exploratory study in which there is no methodological need to make statistical generalizations to any population beyond the sample studied.

In essence a hybrid research methodology strategy was used to perform an empirical investigation of product development practice. The research process used structured and semistructured questionnaires and face-toface non-directive interviews with 21 project managers to gather both qualitative and quantitative data. The data collected from $37 \mathrm{~h}$ of interviewing amounted to 500 pages of transcripts, which were analysed using the Miles and Huberman [34] techniques of content and operational link analysis. The research findings were validated through a series of industrial and academic focus group workshop events.

\section{RESEARCH FINDINGS}

\subsection{Formal organizational boundaries and the division of labour}

Over the last 20 years the Rover Group organization had undergone three primary changes in organizational structure. These are shown in Table 1 according to their time periods and the vehicles launched within that organizational structure.

Figure 2 shows project performance, based on a combined assessment of project cost, quality and timeto-market targets, peaking during Rover Group's teambased organization structure. A key characteristic of this organizational form was increased decentralization.

Table 1 Changes in organizational structures

\begin{tabular}{lr}
\hline Changes in organizational structure within product development & $\begin{array}{l}\text { Approximate } \\
\text { time period }\end{array}$ \\
\hline Functional to lightweight matrix & $1980-1990 / 91$ \\
Vehicles launched: Metro, Maestro & $1990 / 91-1995$ \\
Lightweight to heavyweight matrix to project team & $1995 / 96-1999$ \\
Vehicles launched: Rover 200, Rover 800, Rover 600, Rover 200 Coupe/Cabriolet & Project team to heavyweight matrix to lightweight matrix \\
Vehicles launched: Rover 400, Rover 75 & \\
\hline
\end{tabular}




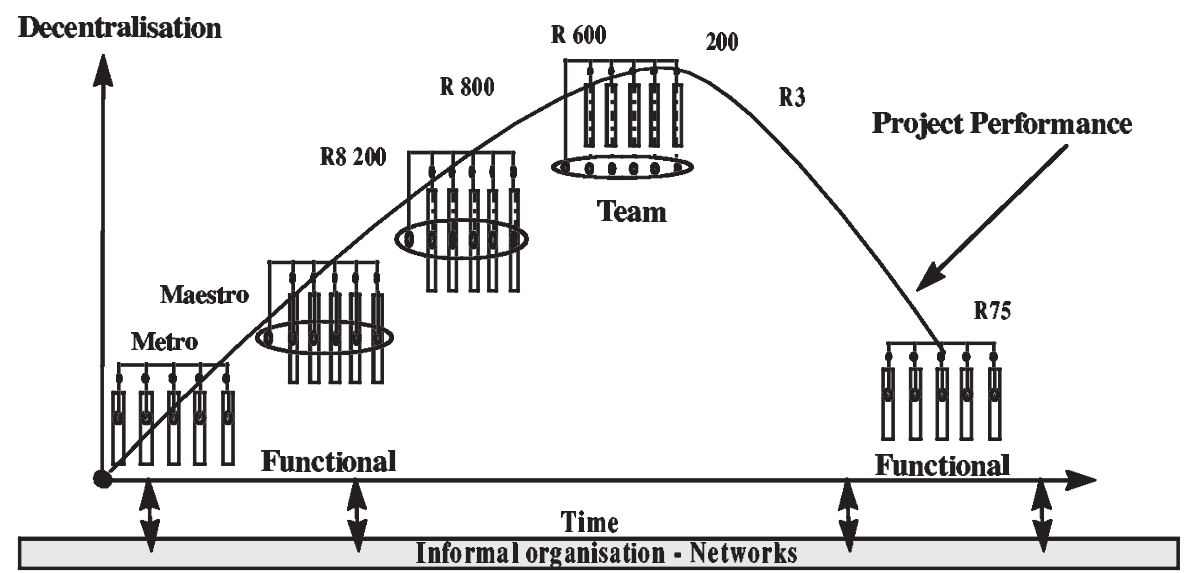

Fig. 2 Formal organization and project success

This ensured that decision-making authority was not centralized by functional departments (or 'home functions'), but devolved out to the project teams. The implementation of a more functional organization had begun to show a decline in project performance.

Over this period of time an interesting pattern had arisen between the formal organizational structure adopted at a strategic and policy level and that which was implemented at an operational level, in the running of product development projects. It became apparent that to a greater or lesser degree of sophistication 'interdisciplinary' working or de facto teamworking was occurring at the operational level, informally, throughout the three different time periods. It was particularly prevalent during the Metro/Maestro projects and was an example of an informal organization, which will be discussed in later sections. The presence of this organization detracted from establishing a clear relationship between formal organization and project success. It was difficult to assess the relative contributions of the formal and informal organizations to project performance without further research.

Like Rover Group, all organizations create formal boundaries around their resources for the purposes of differentiation. Resources or 'labour' were divided in three ways. The first involves the segmentation of different engineering centre of competence $(\mathrm{CoC})$ skill areas (e.g. powertrain, body in white, electrical). This forms the first boundary and has been called the 'skills-division of labour' (s-dol) boundary. It allowed for the differentiation of tasks that need to be carried out to create a product. The second boundary was apparent in terms of how that 'labour' was to be managed and has been called the 'management-division of labour' (m-dol) boundary. This boundary decides whether the skills are to be managed centrally (i.e. functional management style) or whether they are decentralized (i.e. team management style) or in a form that falls along this continuum. The m-dol boundary acted as a 'labour' grouping mechanism. The hierarchy shows formal power, status and rank differentials. The third boundary was a geographical boundary and is concerned with the physical location of 'labour'. This boundary has been called the g-dol boundary. All three boundaries have existed during Rover Group's entire history and have been formally moved regularly over the last 20 years. This movement had often been done independently of long-term business strategy and therefore without any conscious alignment. The formal organization and its s-dol, m-dol and g-dol boundaries are shown in Fig. 3 and are mapped on to an illustrative hierarchical organization structure.

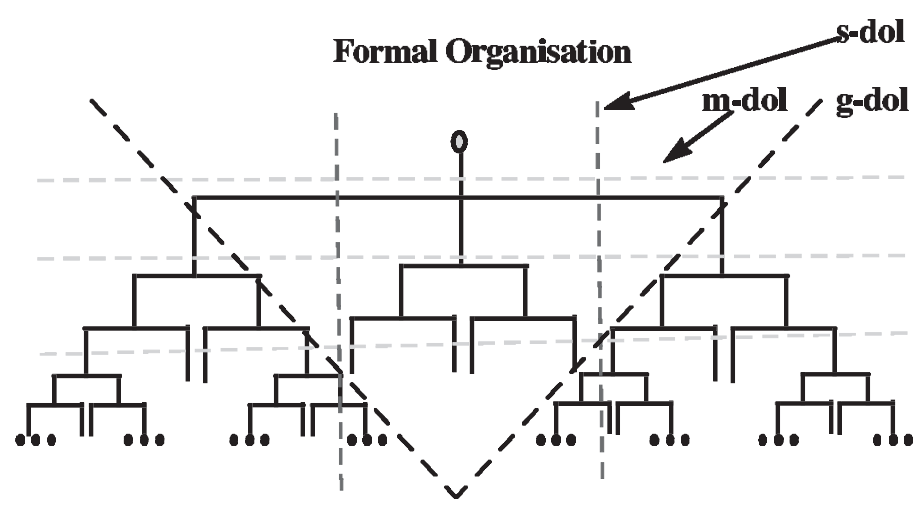

Fig. 3 Formal organizational boundaries 
The previous 20 year period had witnessed greater degrees of functional specialization in the engineering CoC departments. Greater degrees of specialization had led to an increase in the s-dol boundaries. This increase required further organizational efforts to manage them through a subsequent increase in the number of m-dol boundaries.

The formal organization boundaries were static and they encapsulated individuals' professional skills portfolios and how and by whom they were managed. Traditionally they were imposed by the formal organization and enabled the easier coordination of different skill groups around product development task activities. They existed throughout the product development process and were seen to be necessary to maintain a degree of order to avoid a state of 'commercial anarchy'. A similar point has been expressed by Ashkenas et al. [35].

\subsection{Formal organization linkages}

Rover Group's formal organization boundaries recognize the need for individuals to work together to develop a final product. Therefore it prescribed 'links' between individuals with similar or different s-dol, m-dol and gdol boundaries. These links were activated around the definition and delivery of a product development task. Figure 4 shows the 'task' to be the primary link between individuals (or even groups) in the formal organization.

In a stable market environment the formal organization can afford to display high degrees of prescription about the definition of a task and even how it should be delivered (e.g. design, manufacturing and process methodologies). However, the automotive industry operates in a highly dynamic market environment, which is becoming increasingly demanding, fragmented and saturated in some sectors. This has particularly been portrayed in the work of Womack et al. [36], Clark and Fujimoto [37] and more recently Cusamano and Nobeoka [20]. It is also affected by widespread technological developments in design and process technologies and materials. This business climate has generated changes in the nature of product development task activity by increasing levels of specialization, complexity, interdependence and uncertainty. This is shown in Fig. 5.

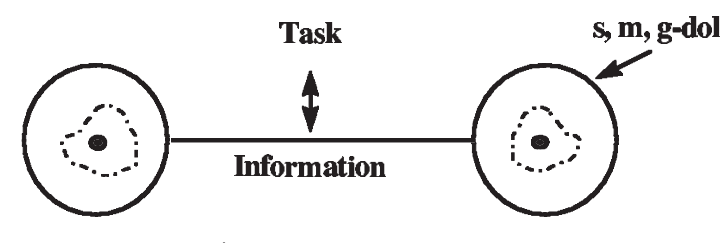

Product Developer A

Product Developer B

Fig. 4 Formal organization link

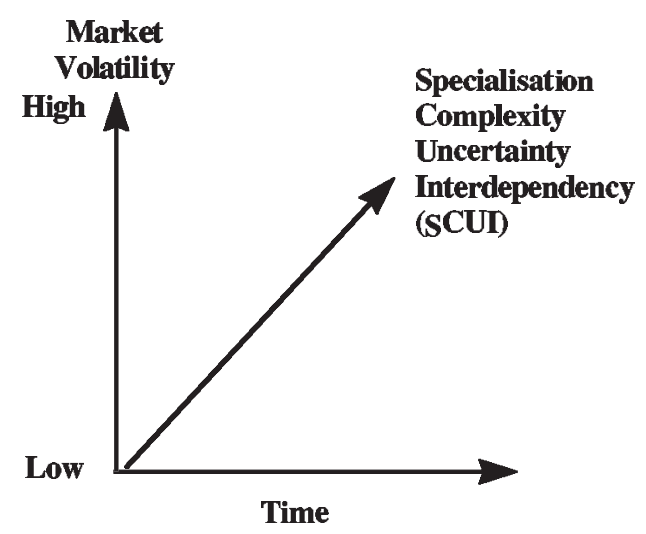

Fig. 5 Changes in product development task activity

In Rover Group greater specialization and complexity required more people with yet more expertise or knowledge (i.e. further classification and division of skills) to work together. In addition to the potential increase in organization size there was an increase in vertical (more hierarchical layers), horizontal (greater division of labour and functional specialization) and spatial (more locations) differentiation. Consequently there was a knock-on increase in the total number of formal boundaries. Baker [12] warns that it is important to realize that increased specialization, as well as requiring increasing numbers of specialists, creates a need for 'generalists' to act as integrative devices.

Increasing levels of differentiation inside the Rover Group led to inward focusing group biases generated by distinct emotional and cognitive stances that impeded the potential for interdepartmental and interunit integration. This finding is consistent with those of Lawrence and Lorsch [38] and Partington et al. [39]. The situation was perpetuated by geographic dispersion of functional departments and units, which created distinct subcultures that again reduced the potential of interfunctional or interunit integration through a lack of close working relationships and ties. In Rover Group's case these subcultures were between the Longbridge, Solihull and Oxford sites.

Coping with Rover Group's increasing market uncertainty required higher levels of interdependence between the various engineering CoCs. Interdependence was better managed in a more team-based organizational structure where product developers with different skills obtained complete or partially complete information from each other efficiently and effectively. This allowed for more productive and integrated problem solving through more parallel working. The whole process relied on team members' appreciation of each other's contributions to the product development process.

The aggregate effect of changes in the nature of Rover Group's product development task activity increased the amount of 'non-routine' activity that needed to be pursued as part of a project. This finding is in congruence 


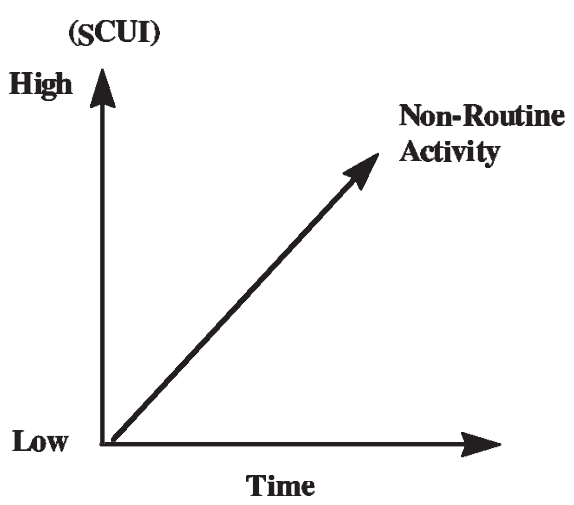

Fig. 6 Changes in product development task activity: nonroutine activity

with Baker's research [12]. This is shown in Fig. 6. In Rover Group's case this situation was intensified by its collaborative relationship with Honda and subsequently BMW AG. Rover Group did not 'own' or 'control' all the skills required for product development.

Finally, market dynamism due to increasing specialization, complexity, interdependence and uncertainty in product development task activity had made it impossible for the formal organization to remain prescriptive about where to place its s-dol, m-dol and g-dol boundaries. The increase in non-routine product development task activity was unmanageable by the formal organization. As a result an informal organization of networked interactions was seen to be set into motion. This is discussed in more detail in the section below.

\subsection{The informal organization}

Table 2 presents the main findings from the 'Working the Boundaries' feasibility study, regarding the 'informal organization'. They are explained in the sections that follow:

Well, does it really matter how you organise the company, or what the functions are, or what the organisation inside the functions are. If you've got the kind of culture that recognises that, you know, a project or set of projects are nothing more than conversations or relationships with people. How you have those conversations and how you deal with the people, enables them to push limits (Project Manager, Rover 200).

Beneath the veneer of the organisation in terms of accountability, reward, responsibility and all the things that come through formal organisational structure, the actual way we work is a very, umm in a positive way, a very chaotic, cooperative, let's all muck in, and that's very culturally ingrained in people (Project Manager, Mini).

The informal organization network presented connections that overlay the traditional formal organizational chart as shown in Fig. 7. The two organizational structures seem to exist in 'tandem' and are able to take advantage of each other's strengths and weaknesses. For example Krackhardt and Hansen's study [10] revealed the strength of the informal organization to include the discovery of informal advice, trust and communication networks and relationships which were critical for improving product development performance.

Seventy-six per cent of project managers reported the importance of the informal organization's contribution to product development project success. Informal relationships between product developers crossed formally prescribed boundaries and were observed as a means of repositioning the rigid formal boundaries, which hindered the efficient and effective flow of communication (i.e. information, ideas, knowledge and experience). The decision to reposition an individual boundary was made at the individual level while determining the new position of the new informal boundary was done in consultation with other colleagues through a process of negotiation.

The changing nature of Rover Group's product development tasks generated new and non-routine tasks that required a division of labour that was undefined by the formal organization. To prevent them

Table 2 Project managers' responses

\begin{tabular}{|c|c|}
\hline & Research findings: non-directive interviews \\
\hline $76 \%$ & Recognized the importance of the informal organization to product development project success \\
\hline $33 \%$ & $\begin{array}{l}\text { Suggested the type of formal organization did not matter so long as the interactions between product developers were not constrained by } \\
\text { formality }\end{array}$ \\
\hline $14 \%$ & Suggested informal organization was more important than the formal organization and was how tasks were completed \\
\hline $66 \%$ & Recognized the significance of productive relationships to product development project success \\
\hline $57 \%$ & Recognized collocation as a mechanism for improving personal interactions between product developers \\
\hline $42 \%$ & Used motivational techniques to encourage team members to form productive relationships \\
\hline & The following factors were seen to make an important contribution to the strength of relationships between product developers: \\
\hline $33 \%$ & Common experience \\
\hline $42 \%$ & Trust \\
\hline $14 \%$ & Respect \\
\hline $28 \%$ & Social context \\
\hline $10 \%$ & Suggested established relationships have a 'residual value' that is associated with the degree of 'relatedness' between those involved in them \\
\hline $19 \%$ & Portrayed relationship-based friendship outlasting the time frame of numerous product development projects \\
\hline
\end{tabular}




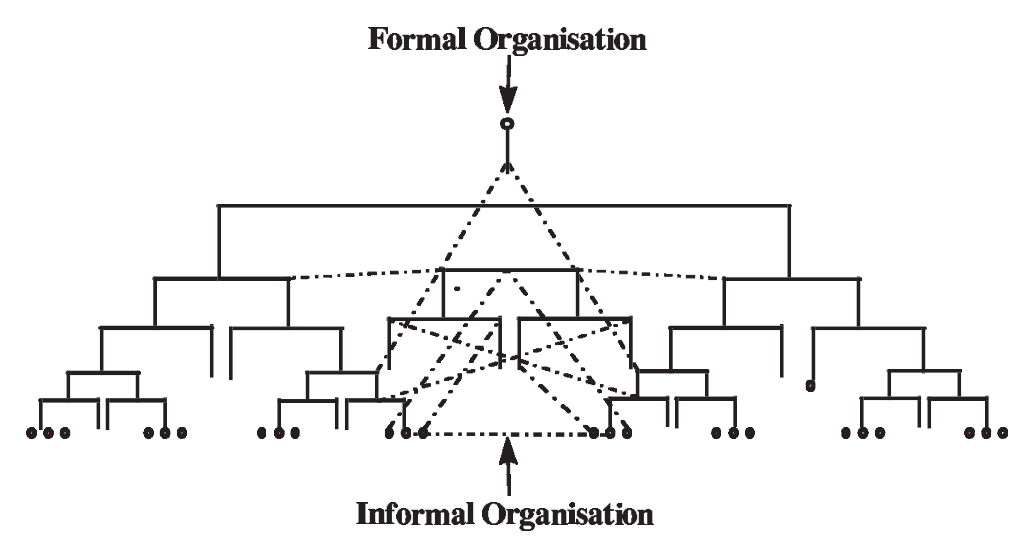

Fig. 7 Formal and informal organizations

falling in the gaps between formal boundaries and risking non-completion, the informal organization was initiated. In effect the informal organization managed the division of labour between formal organizational boundaries, by setting new informal boundaries around a fused set of mixed skills. The informal organization to a large extent self-generated, self-organized and selfmanaged an 'informal division of labour' with a unique set of informal s-dol, m-dol and g-dol boundaries. This is shown in Figs 8 and 9. Eccles and Crane [26] also identified this self-adaptability feature of the network organization and called it the self-designing organization.

The informal organization emerged from Rover Group's existing formal organization structure. The emergent nature of the informal organization has also been noted by Lewin et al. [40]. It enabled networks of unprescribed interactions, between product developers, to take place in multiple directions across the prescribed links of the formal organization. It provided new channels for communications flows to be processed more rapidly and with better quality than would be typical in the formal organization. Interactions and communications in the informal organization were shown to short cut up to six m-dol/s-dol boundaries in the formal organization. An important feature of the informal organization was that tasks were pursued by the shortest path to the right people in the organization rather than those formally responsible for them:

Networking, very important. I mean that's how project teams that's how the whole company works. It doesn't matter what the (formal) organisation is, ... we all have to get the job done. So as long as you know who can help, and do things, via the old network scheme, you get the right guy on the phone and you talk to him, explain, which is why project teams, I think are better, because they give you that freedom, and everybody has that responsibility. So you're all working for a common aim, and we're moving forward (Project Manager, Rover 600).

[The formal organization] won't work. You know, within reason, within the structure. Don't get me wrong, it's not a free for all. But it's the informal way that gets the work done, and gets the job done (Project Manager, Rover 400).

The informal organization appeared well suited to managing product development task activity in Rover Group's dynamic market environment that demanded flexibility. However, although Baker [12] suggests that

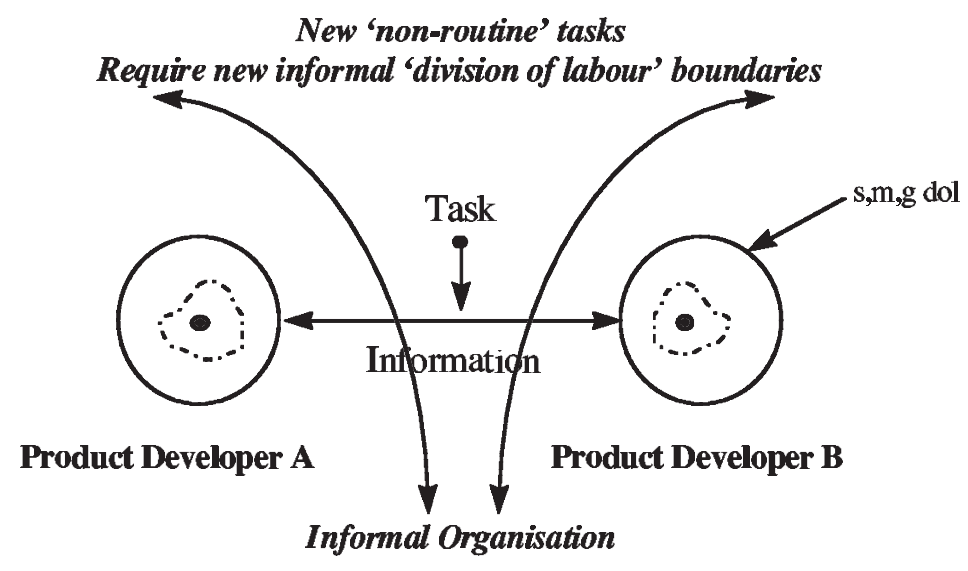

Fig. 8 Informal division of labour 


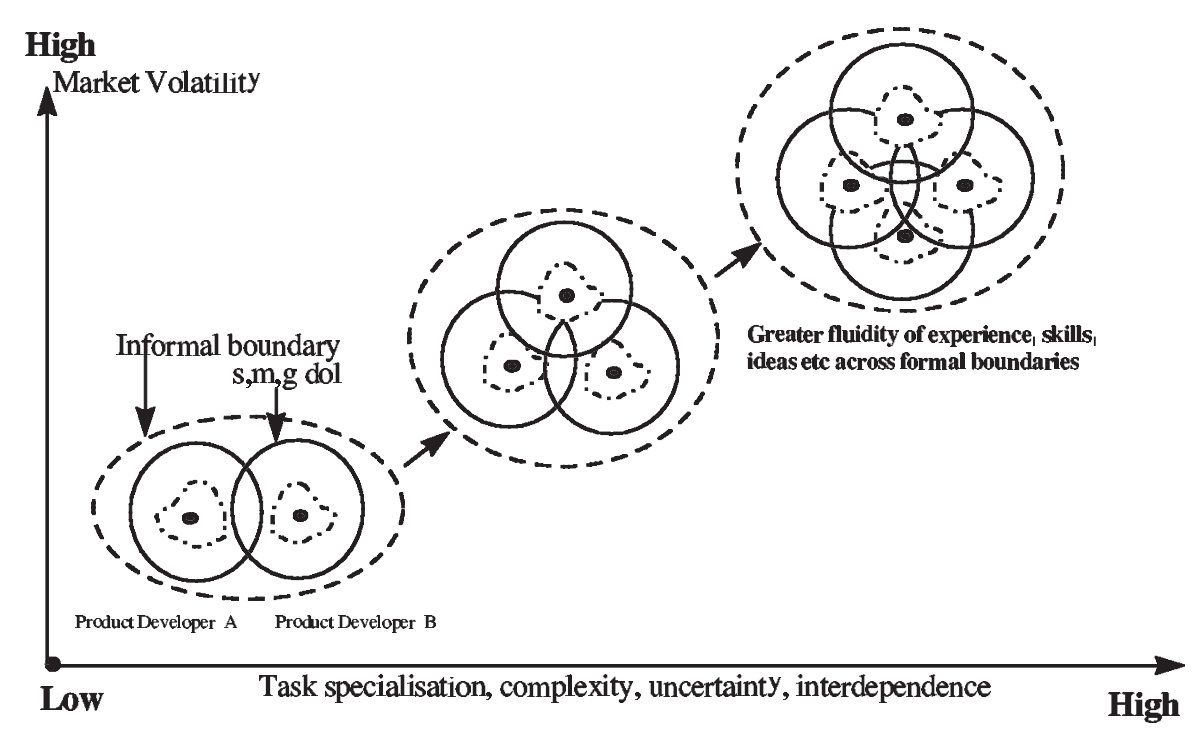

Fig. 9 Market volatility and changes in product development activity

the potential for constructing new sets of links for each product development project is high, in the present research it was found that they were generally confined internally to the project rather than being external to it. There were insufficient data to determine just how fast moving the informal networks really were. In comparison with the traditional functional and hierarchical organization, which presented a rigid set of relationships for processing problems, the dynamism of the informal organization shapes itself around particular product development problems. A sufficient degree of autonomy, through a process of empowerment, was exercised by product developers engaging in these informal and networked interactions to form 'productive relationships'. The informal organization was seen to be an important mechanism for informally allocating people and other resources to tasks in a decentralized fashion. In essence the informal organization could be observed as an attempt to identify effective 'product development project communities'. The recent work of Wenger and Snyder [41] suggests that organizations that operate 'communities of practice' enable the effective sharing of formal and informal organizational resources.

DiMaggio [42] believes the informal organization is constantly emerging and unstable and therefore cannot be relied on for directing future action. She goes on to comment that its capacity for change and managing change is immense, hence its suitability for pursuing product development in dynamic markets. Its structural properties delineate a high degree of integration across formal organizational boundaries. Wasserman and Faust [43] have shown them pictorially using sociomethodology mapping techniques to present network patterns of relationships.

Integration occurs via different types of relationships across formal organization boundaries and varies in strength. Existing theories such as those of Lawrence and Lorsch [38], Ashkenas et al. [35] and Nohria and Eccles [13] only consider the concept of integration across vertical, horizontal and spatial boundaries. This research has shown the importance of integration to be viewed also across time boundaries. The importance of this boundary became apparent when informal relationships reported by 52 per cent of project managers survived many formal organization structure changes over time and remained intact even when product developers no longer worked within the same organization. This presented some indication of the strength of the informal organization. The informal organization allowed for the creation of long-lasting links between individuals, which were exploited for the purposes of product development outside the realms of a single project and at a much later date. Furthermore, 19 per cent of project managers commented how their relationships based on friendship had outlasted several product development projects.

The following section discusses Rover Group's highly acclaimed team-based organization. Both the structural characteristics of the informal organization and the team-based organizations portrayed a high level of integration across formal boundaries. The team-based organization was a positive step taken by Rover Group's management to improve product development performance from a formal organization level. In contrast, the informal organization emerged as a result of the efforts of individuals who were assigned to product development projects.

\subsubsection{Teams and the informal organization}

It appears that the implementation of Rover Group's team-based or 'Business Unit' organization structure was to a large part due to 'boundary gaps' in the traditional functional organization. This organizational form was criticized for creating gaps in communications 
between product developers from different engineering $\mathrm{CoC}$ areas by 33 per cent of project managers. These gaps were being filled by non-routine tasks, which were being realized sooner in a collocated team environment where information was being transmitted between product developers more quickly through informal communication channels. In such a dynamic environment the rigid formal boundaries of the functional organizational structure were considered unsuitable by 52 per cent of project managers. This is also supported by the work of Burns and Stalker [17], Mintzberg [32] and Miles and Snow [25].

The Business Unit environment formally approved and implemented the de facto teamworking practices at Rover Group. General impressions were that Rover Group's Business Unit organization was associated with higher levels of product development project success as shown by the commercial success of the Rover 200 and 400 series. Although it was an organizational form favoured by 76 per cent of the project managers and recommended by 38 per cent as a future organizational strategy it was not problem free. In fact 90 per cent of project managers suggested that the maturation of this organizational form was beginning to unveil the problematic issues associated with organizational learning. These issues reduced the degree of relatedness between product developers in the following contexts:

(a) from product development teams to other product development teams;

(b) from product development team members and their home functions.

Figure 10 shows how the implementation of teams began to generate new formal boundaries between different teams and team members and their home functions. Similar limitations of the team-based organization regarding organizational learning have been previously echoed in the work of Francis and McIntosh [8] and Sobek et al. [5]. More recently Swan et al. [44] at Warwick Business School and Partington et al. [39] at Cranfield School of Management have been carrying out studies of how knowledge and learning are managed in project-based work.
Regardless of the problems of organizational learning, the benefits of the team-based organization have been exposed by many researchers $[\mathbf{1}, \mathbf{2}, \mathbf{4 5}-\mathbf{5 2}]$. The benefits of multidisciplinary teamworking for Rover Group's product development project performance appeared to be associated with lower levels of prescription surrounding product development task activity. Lower levels of prescription were particularly pertinent to effective and efficient communication across formal boundaries. Lower levels of prescription appeared to benefit project performance by limiting formality surrounding the relationships between product developers regarding what tasks need to be completed and how they were to be carried out. This was an important similarity between the team-based and informal organizations. It also helps to understand why some project managers used terms like 'all muck in environment', 'anarchic', 'cooperative' and 'chaotic' to describe the teamworking organization.

In the light of Henderson's view that overcoming organizational boundaries is key to company achievement, two points can be made. Firstly, it is suggested that the formal organization provides a necessary degree of order and skill differentiation for product development activity. Secondly, Rover Group's experiences show that, regardless of the formal organization structural type, formal boundaries needed to be overcome, to ensure the necessary flow of communication for successful product development task activity. Consequently the informal organization was actively engaged to pursue, in particular, non-routine product development activity. This informal organization was more prolific under the team-based organization, which had lower levels of organizational prescription associated with its formal boundaries. This appears to suggest that some formal organization types may be more suited to the development of an informal organization.

\subsubsection{Productive relationships}

It was deduced that the basic contextual unit in which the informal organization operated is the informally generated, organized and managed 'relationship'. The

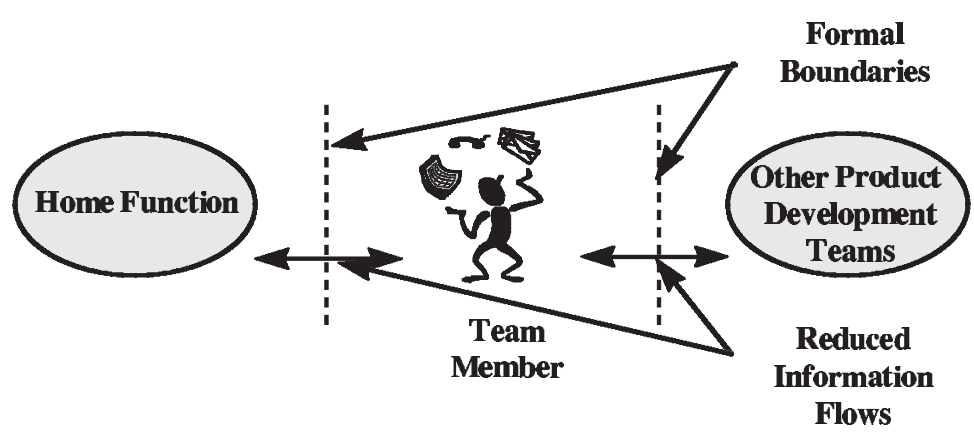

Fig. 10 Formal boundaries 
Table 3 Grounded theoretical developments

\begin{tabular}{|c|c|}
\hline Consistent & $\begin{array}{l}\text { 1. Formal organization boundaries arose as a result of the formal 'division of labour' of the product development task. } \\
\text { 2. Consistent presence of an 'informal organization' of networked relationships existed independently of changes in 'formal } \\
\text { organization'. } \\
\text { 3. The informal organization is a response to the changes in the nature of product development task activity. }\end{array}$ \\
\hline \multirow[t]{3}{*}{ New } & $\begin{array}{l}\text { 1. The informal organization enabled the efficient and effective repositioning of formal boundaries to allow better flow of ideas, } \\
\text { knowledge, experience, etc. In doing so it became the mechanism for overcoming formal organization boundaries. Project } \\
\text { performance (pp) appeared to be a function of the effort to informally reposition the boundaries }(e) \text { : } \\
\quad \mathrm{pp}=f(e)\end{array}$ \\
\hline & $\begin{array}{l}\text { 2. The effort to reposition formal boundaries is a function of the attributes of formal boundaries, individual and the type of product } \\
\text { development task: } \\
\qquad \sum e=f(\mathrm{~s} / \mathrm{m} / \mathrm{g}-\mathrm{dol})+f(i)+f(t)\end{array}$ \\
\hline & $\begin{array}{l}\text { 3. The informal organization appeared to be self-generating, self-organizing and self-managing and represented 'product } \\
\text { development project community'. } \\
\text { 4. Existing theories only consider integration across vertical (skills), horizontal (authority) and spatial (geographical) boundaries. } \\
\text { Integration must also be viewed across time boundaries. }\end{array}$ \\
\hline Proposed & $\begin{array}{l}\text { 1. Productive relationships may have a 'residual value' that is associated with the 'degree of relatedness' between the product } \\
\text { developers. } \\
\text { 2. Relationships should be considered in the form of a dynamic 'lifecycle' process. } \\
\text { 3. The informal organization manages an informal division of labour with its unique set of informal boundaries. }\end{array}$ \\
\hline
\end{tabular}

significance of these productive relationships to product development project success was recognized by 66 per cent of project managers. Formalized communications strategies such as collocation were recognized by 57 per cent of project managers as a mechanism to improve personal interactions between product developers. Furthermore, motivational techniques were used by 42 per cent of project managers to encourage the formation of informal relationships.

Other researchers such as Athaide and Stump [15] have shown the need for organizations to manage their relationship building capabilities as well as their technological capabilities. Similarly, Liedtka et al. [14] suggest that mastering organization capabilities to learn and collaborate and managing knowledge and relationships is the foundation for competitive success in the future.

In this research the importance of trust and respect were cited as important contributors to the strength of the relationships between product developers by 42 per cent and 14 per cent of project managers respectively. It was suggested that further strengthening of these relationships could effectively occur in more social contexts away from the everyday workplace. Typical events such as outward-bound team building events and after-work socializing were suggested by 28 per cent of project managers.

The use of the term 'trust' has recently received significant academic attention in the management science arena [53-55]. Recent research by Bouty [16] and Gulati et al. [27] advocates productive relationships based on trust to allow a higher degree of risk to be taken in decision making. Without high levels of risk in decision making, innovation may be curtailed. This is pertinent to project performance in a dynamic market environment.

A small 10 per cent of project managers suggested that these productive relationships can be considered to have a 'residual value' which may be associated with the degree of 'relatedness' between those involved in them. The degree of relatedness between product developers is dependent on the 'lifecycle' experiences of the relationship between them. It is hypothesized that these life experiences can demonstrate how and why relationships form, develop and are maintained. In the collocated team-based organization people had greater opportunities to form relationships more readily and therefore the total amounts of relatedness and residual value are potentially higher.

\subsection{Grounded theoretical developments}

The previous sections have discussed the research findings in the context of existing theory. The theoretical developments are summarized in Table 3 under the following categorization:

(a) those consistent with existing theory;

(b) those new to existing theory;

(c) those proposed for further research.

\section{CONCLUSIONS}

\subsection{Research hypothesis revisited}

This research suggests that companies such as Rover Group who operate in a dynamic business environment 
and rely on effective and efficient multidisciplinary working would benefit in designing formal organizations that encourage the formation of informal networks. It is the belief of the present authors that all types of formal organization have their life span and usually only bring short-term success, unless the boundaries of the established organizational form are acted on. For example, even Rover Group's state-of-the-art team-based organizational form brought a new set of formal boundaries to contest with. Product development performance was beginning to decline, as the new boundaries were not being overcome adequately.

The 'Working the Boundaries' research project has determined the feasibility of a 'boundary-based' view in organizing human resources during product development. Essentially, this view stresses the need for firms to consider not only the strategic placement of formal organizational boundaries but also the concurrent ongoing development of innovative options for overcoming them.

This paper has presented some grounded theoretical developments, which are supporting Henderson's view that overcoming organizational boundaries is key to company achievement. Further findings are echoing those of Krackhardt and Hanson [10], Farris [11], Baker [12], Nohria and Eccles [13], Liedtka et al. [14], Athaide and Stump [15] and Bouty [16].

The theoretical developments from this research have important implications for both the industrial and the academic communities. Industrialists wanting to improve product development performance cannot simply rely on changing the formal organizational structure. They need to make explicit the recognition of their current informal organization and its network of productive relationships. More academic research is required to support this endeavour.

\subsection{Further research}

Recent theories surrounding the research topic have focused on the structural characteristics of networks and informal organizations rather than its contextual unit - the relationship. Little attention has been given to how the networks and relationships between product developers are formed, developed, maintained and used. This research has shown current limitations of network organization theory scope: the dynamic element of the 'lifecycle' of a relationship or network link.

\section{ACKNOWLEDGEMENTS}

The authors would like to thank everyone at the Rover Group arm of the BMW AG Corporation who has participated in the research process. Without their kind efforts this work would not have been possible.

\section{REFERENCES}

1 Brookes, N. J., Backhouse, C. J. and Burns, N. D. Concurrent engineering: how can we decide what works where? In Proceedings of 31 st International Matador Conference (Ed. A. K. Kochhar), London, 20-21 April 1995, pp. 493-498.

2 Lettice, F. E. Concurrent engineering: a team-based approach to rapid implementation. PhD thesis, CIM Institute, School of Industrial and Manufacturing Science, Cranfield University, 1995.

3 Shina, S. G. (Ed.) Successful Implementation of Concurrent Engineering Products and Processes, 1994 (Van Nostrand Reinhold, New York).

4 Syan, C. S. and Menon, U. Concurrent Engineering: Concepts, Implementation and Practice, 1994 (Chapman and Hall, London).

5 Sobek, D. K., Liker, J. K. and Ward, A. C. Another look at how Toyota integrates product development. Harv. Business Rev., July-August 1998.

6 Song, M., Thieme, R. J. and Xie, J. The impact of crossfunctional joint involvement across product development stages: an exploratory study. J. Prod. Innovation Managmt, 1998, 15, 289-303.

7 Drucker, P. The future that has already happened. Harv. Business Rev., September-October 1997, 75(5), 20-24.

8 Francia, A. and MacIntosh, R. The market, technological and industry context of business process re-engineering in the UK. Int. J. Ops Prod. Managmt, 1997, 17(4), 344-364.

9 Henderson, R. Managing innovation in the information age. Harv. Business Rev., 1994, reprint 94105.

10 Krackhardt, D. and Hanson, J. R. Informal networks: a company behind the chart. Harv. Business Rev., JulyAugust 1993.

11 Farris, G. F. Groups and the Informal Organisation, 1981 (John Wiley, New York).

12 Baker, W. The network organisation in theory and practice. In Networks and Organisations: Structure, Form and Action (Eds N. Nohria and R. G. Eccles), 1992 (Harvard Business School Press, Boston, Massachusetts).

13 Nohria, N. and Eccles, R. G. Networks and Organisations: Structure, Form and Action, 1992 (Harvard Business School Press, Boston, Massachusetts).

14 Liedtka, J. M., Haskins, M. E., Rosenblum, J. W. and Weber, J. The generative cycle: linking knowledge and relationships. IEEE Engng Managmt Rev., 1999, 27(1).

15 Athaide, G. A. and Stump, R. L. A taxonomy of relationship approaches during product development in technology based, industrial markets. J. Prod. Innovation Managmt, 1999, 16, 469-482.

16 Bouty, I. Interpersonal and interaction influences on informal resource exchanges between $R \& D$ researchers across organisational boundaries. Acad. Managmt J., 2000, 43(1), 50-65.

17 Burns and Stalker

18 Grover, V. From business reengineering to business process change management: a longitudinal study of trends and practices. IEEE Trans. Engng Managmt, February 1999, 46(1), 36-46.

19 Crainer, S. Key Management Ideas: Thinkers that Changed the Management World, 1996 (F. T. Pitman Publishing, London). 
20 Cusamano, M. A. and Nobeoka, K. Thinking Beyond Lean: How Multi-Project Management is Transforming Product Development at Toyota and Other Companies, 1998 (Free Press, New York).

21 Tatikonda, M. V. An empirical study of platform and derivative product development projects. J. Prod. Innovation Managmt, 1999, 16(3-6), 3-26.

22 Ward, S., Light, L. and Goldstine, J. What high-tech managers need to know about brands. Harv. Business Rev., July-August 1999.

23 Argyris, C. Interpersonal Competence and Organisational Effectiveness, 1962 (Tavistock, London).

24 Mintzberg, H. Structures in Fives: Designing Effective Organizations, 1986 (Prentice-Hall, Englewood Cliffs, New Jersey).

25 Miles and Snow 1986

26 Eccles, R. G. and Crane, D. B. Managing through networks in investment banking. Calif. Managmt Rev., 1987, 30, 176195.

27 Gulati, R., Nohria, N. and Zaheer, A. Strategic networks. Strategic Managmt J., 2000, 21, 203-215.

28 Burt, R. S. Structural Holes: The Social Structure of Competition, 1995 (Harvard University Press, Boston, Massachusetts).

29 Krackhardt, D. and Kilduff, M. Friendship patterns and culture: the control of organizational diversity. Am. Anthrop., 1990.

30 Newell, S., Swan, J. and Preston, J. Trust and interorganisational networking. In 14th EGOS Colloquium, Maastricht, July 1998.

31 Farris, G. F. Editorial: people and organisations department. IEEE Trans. Engng Managmt, 2000, 47(1).

32 Mintzberg, H. The Structuring of Organisations, 1979 (Prentice-Hall, Englewood Cliffs, New Jersey).

33 Brookes, N. J. and Backhouse, C. J. Measuring the performance of product introduction. Proc. Instn Mech. Engrs, Part B, Journal of Engineering Manufacture, 1998, 212(B1), 1-11.

34 Miles, M. B. and Huberman, A. M. Qualitative Data Analysis: A Sourcebook of New Methods, 1984 (Sage, Beverly Hills, California).

35 Ashkenas, R., Ulrich, D., Jick, T. and Kerr, S. The Boundaryless Organisation: Breaking the Chains of Organisational Structure, 1995 (Jossey-Bass).

36 Womack, J., Jones, D. and Roos, D. Machine that Changed the World, 1990 (Rawson, New York).

37 Clark, K. B. and Fujimoto, T. Product Development Performance-Strategy, Organisation and Management in the World Auto Industry, 1991 (Harvard Business School Press, Boston, Massachusetts).

38 Lawrence, P. R. and Lorsch, J. W. Organisation and Environment: Managing Differentiation and Integration, 1967 (Harvard University).

39 Partington, D., Tranfield, D. and Bessant, J. Studying routines for teamworking and knowledge management: a grounded theory approach to multi-context research in team-based organisations. Working paper, 2000.

40 Lewin, A.Y., Long, C. P. and Carroll, T. N. The coevolution of new organisational forms. Orgn Sci., September-October 1999, 10(5), 535-550.

41 Wenger, E. C. and Snyder, W. M. Communities of practice: the organisational frontier. Harv. Business Rev., JanuaryFebruary 2000.

42 DiMaggio, P. Nadel's paradox revisited: relational and cultural aspects of organisational structure. In Networks and Organisations: Structure, Form and Action (Eds N. Nohria and R. G. Eccles), 1992 (Harvard Business School Press, Boston, Massachusetts).

43 Wasserman, S. and Faust, K. Social Network Analysis: Methods and Applications, 1994 (Cambridge University Press, Cambridge).

44 Swan, J., Scarborough, H., Newell, S. and Bresen, M. Knowledge management for project based learning: a scoping study. Working paper, Warwick Business School WWW Site, 1999.

45 Takeuchi, H. and Nonaka, I. The new product development game-stop running the relay race and take up rugby. Harv. Business Rev., January-February 1986, 137-146.

46 Thamhain, H. J. and Wilemon, D. Building high performance engineering project teams. IEEE Trans. Engng Managmt, August 1987, 34(3), 130-137.

47 Riedel, J. C. K. H. and Pawar, I. The strategic choice of simultaneous versus sequential engineering for the introduction of new products. Int. J. Technol. Managmt, 1991 (Special Issue on Manufacturing Strategy), 321-334.

48 Karagozoglu, N. and Brown, W. B. Time based management of the new product development process. J. Prod. Innovation Managmt, 1993, 10, 204-215.

49 Katzenbach, J. R. and Smith, D. K. The Wisdom of Teams: Creating the High-Performance Organisation, 1993 (Harvard Business School Press, Boston, Massachusetts).

50 Brown, S. L. and Eisenhardt, K. M. Product development: past research, present findings, and future directions. Acad. Managmt Rev., 1995, 20(2), 343-378.

51 Duffy, V., Danek, A. and Salvendy, G. A predictive model for the successful integration of concurrent engineering with people and organisational factors: based on data of 25 companies. Int. J. Hum. Factors Mfg, 1995, 5(4), 429445.

52 Cohen, S. G. and Bailey, D. E. What makes teams work: group effectiveness research from the shop floor to the executive suite. J. Managmt, 1997, 23(3), 239-290.

53 Korczynski, M. The political economy of trust. J. Managmt Studies, January 2000.

54 Adler, P. S., et al. Flexibility versus efficiency? A case study of model changeovers in the Toyota Production System. Orgn Sci., January-February 1999, 10(1).

55 Bachmann, R. Trust, power and control in transorganizational relations. Working paper, ESRC Centre for Business Research, Cambridge University, 1999. 